\section{Features \\ of the echostructure of the abdominal organs in children with ascariasis}

B.A. Tarasyuk ${ }^{1}$, I.S. Lukyanova ${ }^{2}$, I.N. Dykan', O.V. Golovchenko ${ }^{2}$, T.A. Gridina ${ }^{2}$, N.T. Reminnaya ${ }^{2}$

State Institution «Institute of Nuclear Medicine and Diagnostic Radiology of NAMS of Ukraine ${ }^{1}$, Kyiv State Institution «Acad. Ye.M. Lukianova Institute of Pediatrics, Obstetrics and Gynecology of NAMS of Ukraine»², Kyiv
One of the most common parasitic diseases in children is ascariasis, which belongs to the group of anthroponous geo-helminthiasis. The ascariasis pathogen are roundworms - Ascaris Lumbricoides. The disease develops without the involvement of the intermediate host and is transmitted to humans through elements of the environment (soil, vegetables, berries, etc.) contaminated with invasive eggs. The infection path - fecal-oral. World statistics demonstrate that nearly 1 billion people are infected with this helminth each year, with the lion's share being children [1]. Children under 3 years of age $(25.3 \%), 7-9$ years $(11.3 \%)$ and $10-12$ years $(11.9 \%)$ are most susceptible to infection with ascariasis [2].

The clinical course of the disease is characterized by 2 phases: early and late. The early phase is characterized by manifestations in the form of an allergic rash, general weakness, hypersalivation, teeth gnashing, bronchopulmonary inflammation and disorders of the hepatobiliary system function. In the later stage more significant disorders such as decreased appetite, nausea, vomiting, headache, dizziness, signs of meningism, and bowel disorder are registered. The course of the disease can be accompanied by severe complications: pneumonitis, intestinal obstruction, cholecystitis, pancreatitis, liver abscesses and others.

Every year from ascariasis complications dies from 30 to 60 thousand people [7, 11]. To date, the diagnosis of the disease is carried out according to the Kato-Katz method [8] by analyzing the thick smear stool recommended by WHO [12] to determine parasitic infections.

The purpose of the investigation is to study the abdominal organs' echostructure in children with confirmed diagnosis of ascariasis.

\section{Material and research methods}

The study included 45 children of 3-18 years: 21 boys and 24 girls. By age, children were distributed as follows: 3 years -4 persons; $4-7$ years $-18 ; 8-11$ years $-15 ; 12-18$ years -8 . The control group consisted of 35 children with no history of abdominal pain for six months. Of these, 3 children aged of 7 years, 9 - of 4-7 years, $10-$ of 8-11 years, 9 - of 12-18 years.

The main complaints were typical for dyspeptic syndrome: poor appetite -36 children $(90 \%)$, abdominal pain - $40(89 \%)$, irregular stool - 29 (64 $\%$ ). Abdominal syndrome is explained by the reaction of mesenteric lymph nodes as a result of parasite migration through the small intestinal wall $[1,2]$.

All patients underwent clinical and laboratory examinations, which did not detect significant abnormalities in general blood and urine tests, and biochemical blood counts also had no significant deviations. Diagnosis of ascariasis was confirmed by the results of coproscopy.

Ultrasound (US) was performed according to generally accepted protocols on expert-grade ultrasonic devices with convex 3.5-5.0 $\mathrm{MHz}$ and linear 7.5-10.0 MHz probes with dosed compression. The B-mode investigations were complemented by color Doppler mapping (CDM). To evaluate ultrasound semiotics, the following organs were studied: liver - the thickness of both parts and the nature of the texture; gallbladder the size, nature of the contents and wall changes; pancreas - the size of the head, body and tail, the nature of the texture; spleen - the size and texture; lymph nodes - in hepatoduodenal ligament, spleen gates, small intestine mesentery root, and ileocecal (number, mutually perpendicular dimensions (length and thickness), vascular pattern and blood flow pattern). 
Also, 26 patients with ascariasis and 23 children of the control group were investigated with hydrosonography - an ultrasound examination of the upper sections of the digestive tract in terms of their physiological filling by oral administration of non-carbonated water of room temperature. This method allows to study the condition of the digestive tract from the abdominal esophagus to the duodenum, and to evaluate the tone of the walls, the activity of the peristalsis and, accordingly, the evacuation rate of the esophagus, stomach, duodenum contents [3]. The stomach was investigated on an empty stomach and after filling it with water. The volume of fluid depended on the patient's age: 5 years $-150-180$ $\mathrm{ml}, 6$ to 12 years $-200-250 \mathrm{ml}, 12$ and older 300-350 $\mathrm{ml}$. At hydrosonography, attention was paid to the stomach location, the peristalsis nature and the fluid discharge from the stomach to the esophagus.

\section{Results and discussion}

During the investigation, attention was drawn to the structure of the liver ultrasound slices, that were characterized by a certain "brightness" of the vascular pattern in 37 children (82\%) (Fig. 1, Table 2). It should be noted that the liver size in most patients was not increased. At scanning with linear probes, the spectrum of blood flow in hepatic veins of small caliber saved three-phase in all children. At US investigation of the gallbladder in the group with ascariasis and in the control group pathological changes were not detected. The diameter of the common bile duct was not increased and was $3.2 \pm 0.5 \mathrm{~mm}$.

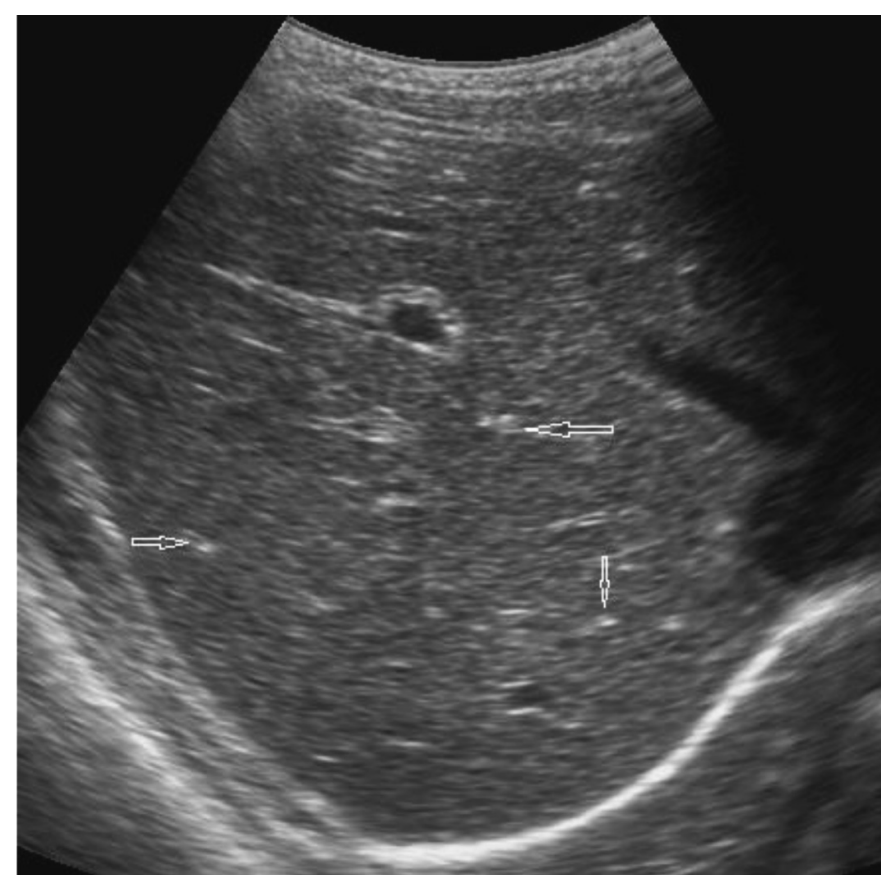

Fig. 1. Liver ultrasound with convex probe in patient with ascariasis. The arrows indicate the tubular structures of increased echogenicity.

Changes in the pancreas were quite diverse, namely: increase in the size of its parts was registered in 15 patients (33\%), tissue echogenicity decrease - in $4(9 \%)$, echogenicity increase - in 9 $(20 \%)$. This fact indicates the absence of characteristic manifestations of the pancreas in children with ascariasis. It is probable that each personal case has its individual reaction.

The spleen in the most cases of ascariasis (39 children $-87 \%$ ) had normal sizes. However, in 6 patients $(13 \%)$, an increase in its length was observed, with unchanged ultrasound parenchyma structure.

Investigation of the abdominal cavity lymph nodes with a linear probe using dosage compres-

Table 1.

Ultrasound characteristics of liver texture in patients with ascariasis and in the control group.

\begin{tabular}{|c|c|c|c|c|c|}
\hline \multicolumn{5}{|c|}{ Liver texture } \\
\hline \multicolumn{5}{|c|}{ Ascariasis } & \multicolumn{3}{c|}{ Control group } \\
\hline Age group/ quantity & Common & $\begin{array}{c}\text { «Bright vascular } \\
\text { pattern» }\end{array}$ & $\begin{array}{c}\text { Age group/ } \\
\text { quantity }\end{array}$ & Common & $\begin{array}{c}\text { «Bright vascular } \\
\text { pattern» }\end{array}$ \\
\hline $3(4)$ & 1 & 3 & $3(7)$ & 6 & 1 \\
\hline $5-7(18)$ & 2 & 16 & $5-7(9)$ & 9 & - \\
\hline $8-11(15)$ & 4 & 11 & $8-11(10)$ & 9 & 1 \\
\hline $12-18(8)$ & 1 & 7 & $12-18(9)$ & 6 & 3 \\
\hline Total & 8 & 37 & - & 30 & 5 \\
\hline Percent & $18 \%$ & $82 \%$ & - & $86 \%$ & $14 \%$ \\
\hline
\end{tabular}


Table 2.

Localization and number of enlarged lymph nodes of the abdomen in children with ascariasis and in the control group.

\begin{tabular}{|l|c|c|c|c|c|c|c|c|}
\hline \multirow{2}{*}{\multicolumn{1}{c|}{ Localization }} & \multicolumn{4}{|c|}{ Ascariasis $(\mathrm{n}=45)$} & \multicolumn{4}{c|}{ Control group (n=35) } \\
\cline { 2 - 10 } & $3(4)$ & $5-7(18)$ & $8-11(15)$ & $12-18(8)$ & $3(7)$ & $5-7(9)$ & $8-11(10)$ & $12-18(9)$ \\
\hline Hepatoduodenal ligament & - & - & 1 & 1 & - & - & - & - \\
\hline Spleen gate & - & 1 & - & - & - & - & - & - \\
\hline $\begin{array}{l}\text { Small intestine mesentery } \\
\text { root }\end{array}$ & 12 & 72 & 68 & 24 & - & 1 & 1 & - \\
\hline Ileocecal & 10 & 50 & 59 & 20 & 2 & 4 & 7 & 5 \\
\hline Total & 22 & 123 & 128 & 45 & 2 & 4 & 7 & 5 \\
\hline
\end{tabular}

sion in the control group deminstrated that the generalized norm is $8.2 \pm 1.6 \mathrm{~mm}$ in length and $3.01 \pm 1.2 \mathrm{~mm}$ in width. As can be seen from Table 2 , at ascariasis the increased size of the lymph nodes most often was registered in the ileocecal area and at the mesentery root. The total number of lymph nodes detected in the group with ascariasis was 318 , and in the control group 18. That is, the response of the abdominal cavity lymphatic system to ascariasis was sufficiently pronounced.

All patients with ascariasis had normal elongated lymph nodes (length-to-width ratio was 1:2) and regular cortical and brain layers differentiation was maintained. Nodes gates, usually oval or triangular, were hyperechogenic (Fig. 2). It is worth noting that in 5 cases a dense location of the ileocecal group of lymph nodes was registered when difficulties in measuring their size occurred. At the CDM, in the cases where the length of the node exceeded $13 \mathrm{~mm}$, the artery and vein were visualized at the gate of the lymph nodes (Fig. 3).

The results of the stomach and esophagus hydrosonography are presented in table 3 .

It is known that the presence of a lumen in the abdominal part of the esophagus and the registration of a reversed fasting fluid flow is a typical sign of gastroesophageal reflux [3] (Fig. 4). In our study, this symptom was found in $73 \%$ of patients with ascariasis and in $13 \%$ of children in the control group. That is, a violation of gastric motility was an additional symptom at ascariasis (Table 3 ).

It should be noted that the gastric wall thickness in the group with ascariasis and in the control group

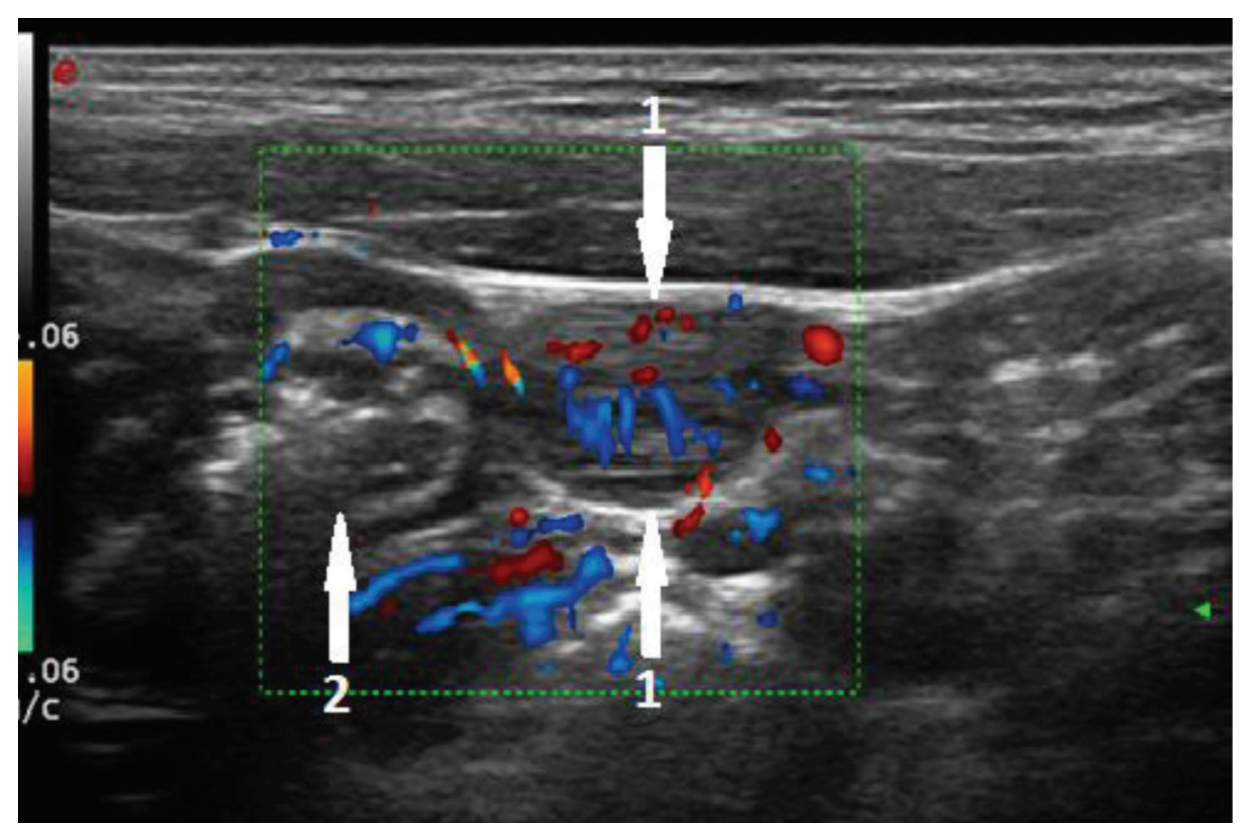

Fig. 2. US of the mesenteric lymph node in the right ileocecal area. 1 -lymph node; 2 -intestines. 


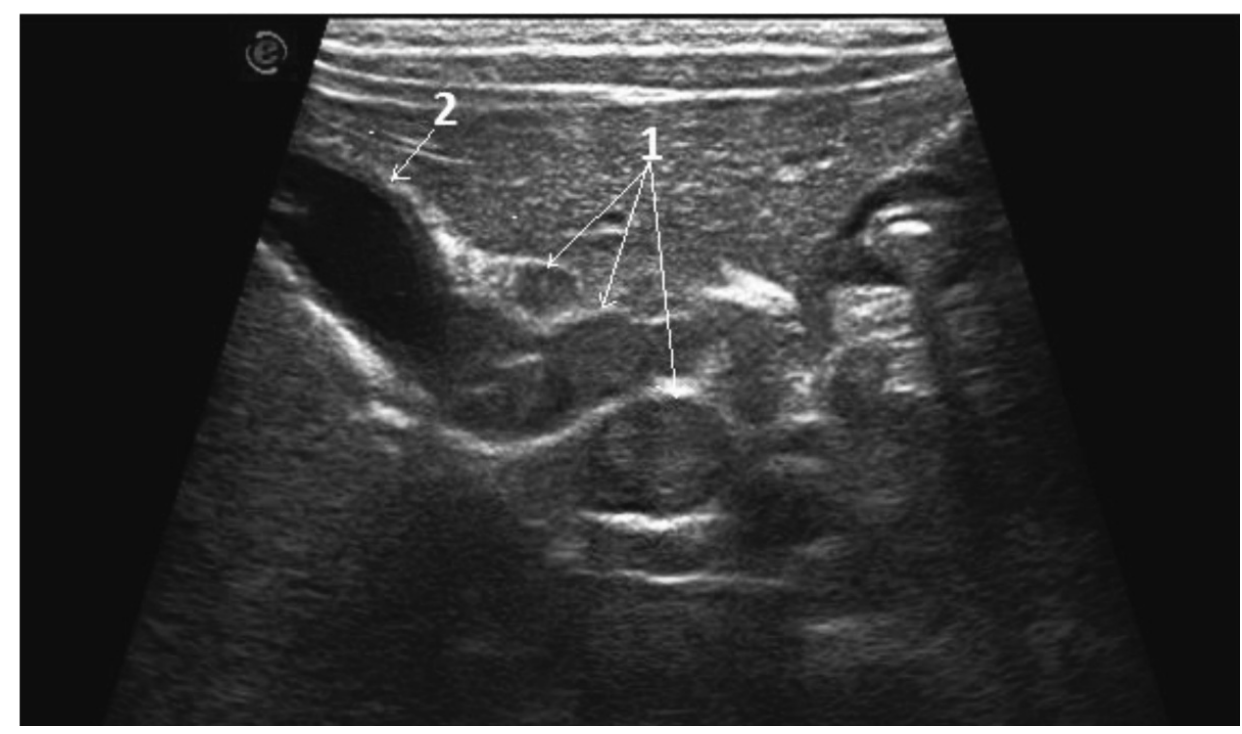

Fig. 3. US of the hepatoduodenal ligament. 1 - enlarged lymph nodes; 2 - gallbladder.

had no significant deviations and corresponded to normal rates.

It is known that the ascariasis course can be accompanied by various complications $[4,7,9]$, as evidenced by the presented clinical observation.

Clinical observation. Child O., a boy of 2.5 years was examined for a previous diagnosis - "Cholestasis? Mechanical jaundice? Choledochal cyst?". The main complaints were vomiting after eating, lack of appetite, skin itching, periodic abdominal pain, periodic skin yellowing, physical development lag over the last 10-11 months. For the first time, a baby got sick at the age of 1.2 when a rash on the body and dyspeptic disorders appeared. He was treated in a hospital. Helminthiasis (eosinophilia up to 10-18 $\%$, hypochromic anemia) was suspected, but it was not confirmed laboratory. Pyrantel was appointed one time. Since then, the dyspepsia symptoms, ane-

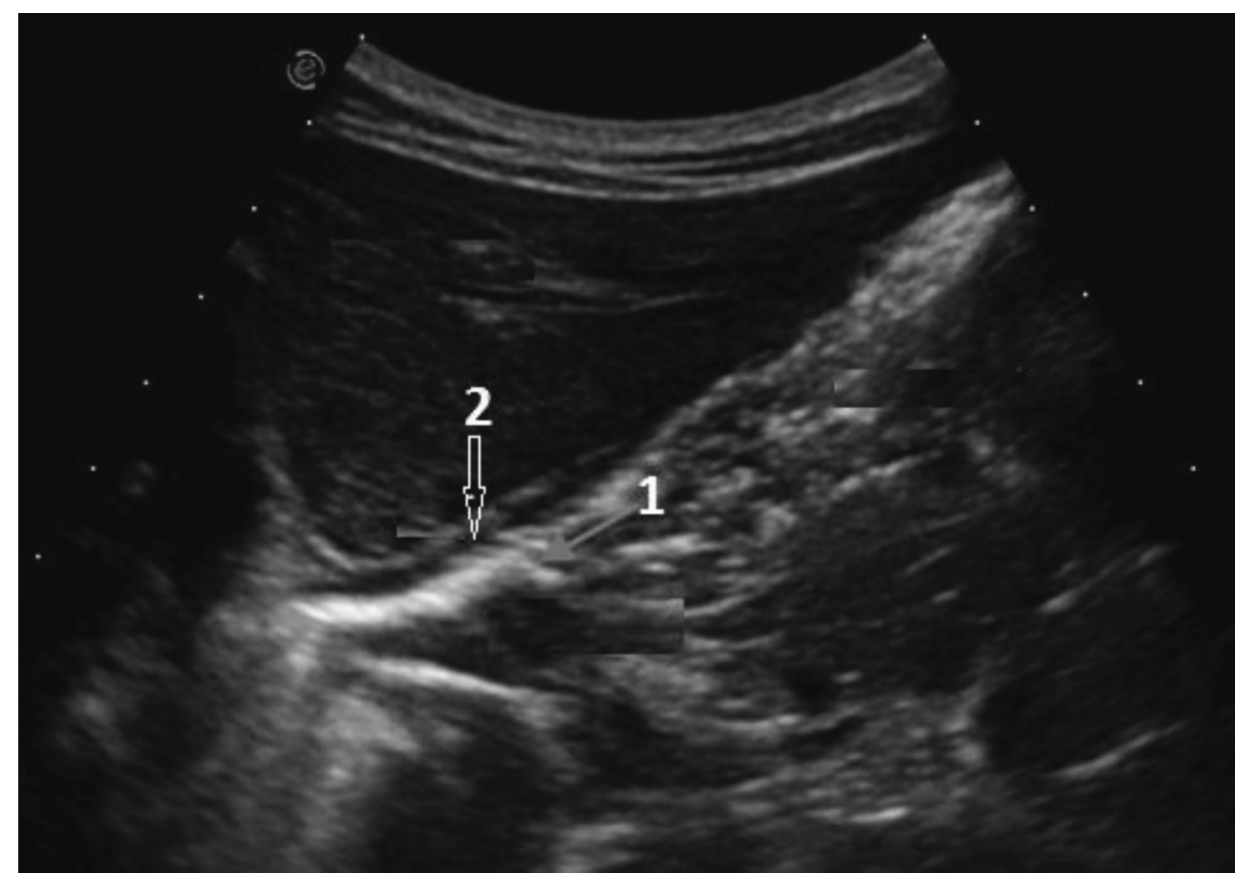

Fig. 4. US of the abdominal esophagus in a patient with ascariasis. 1 - esophagus lumen of the; 2 esophagus wall. 
Table 3.

Ultrasound signs of gastroesophageal reflux.

\begin{tabular}{|l|c|c|c|c|}
\hline \multirow{2}{*}{ Signs } & \multicolumn{2}{|c|}{$\begin{array}{c}\text { Patients with ascariasis } \\
(\mathrm{n}=26)\end{array}$} & \multicolumn{2}{c|}{$\begin{array}{c}\text { Control group } \\
(\mathrm{n}=23)\end{array}$} \\
\cline { 2 - 5 } & Abs. & $\%$ & Abs. & $\%$ \\
\hline $\begin{array}{l}\text { The presence of a large amount of fluid on an empty } \\
\text { stomach }\end{array}$ & 21 & 81 & 10 & 43 \\
\hline Antiperistaltic stomach contractions & 18 & 69 & 8 & 35 \\
\hline $\begin{array}{l}\text { The presence of the lumen of the esophagus and the } \\
\text { discharge of fluid from the stomach to the esophagus }\end{array}$ & 19 & 73 & 3 & 13 \\
\hline
\end{tabular}

mia, weight loss have progressed. Wave-like complaints alternated with periods of improvement. The patient was stationary investigated in the district and regional hospitals, and the helminthiasis has never been confirmed. Objective examination before the time of US investigation demonstrated body weight deficiency (weight $7.9 \mathrm{~kg}$, height $93 \mathrm{~cm}$ ), marked pale and dry skin, moderate pain at palpation in the right hypochondrium. According to the laboratory examination data, hypochromic anemia was found - hemoglobin $88 \mathrm{~g} / \mathrm{l}$, neutrophilosis up to $60 \%$, ESR increase up to $21 \mathrm{~mm}$, ALT - 30 units, AST 38 units, alkaline phosphatase -110 units, bilirubin total $-15 \mathrm{mmol} / 1$, indirect $-4.4 \mathrm{mmol} / 1$, direct $11.6 \mathrm{mmol} / 1$.

At US in the sagittal slices of the gallbladder, in its cavity, a ribbon-shaped echositive structure (without ultrasound shadow) with a less echogenic center was visualized. Its length was $40 \mathrm{~mm}$ and its diameter was $3.5 \mathrm{~mm}$ (Fig. 5, 6).

At scanning, the formation moved freely in the gallbladder cavity. The walls gall bladder were thickened to 3.5-4 $\mathrm{mm}$ [2], that indicated the presence of chronic inflammation. The common bile duct had a diameter of up to $3 \mathrm{~mm}$ without inclusions. Thus, a parasite was identified in the gallbladder, which, according to all US features, corresponded to the ascaris [10]. In this case, the parasite, moving from the duodenum along the common bile duct to the gallbladder, could cause mechanical jaundice accompanied by pain syndrom.

This observation is a confirmation of the fact that in all cases of undetermined abdominal pain, transient jaundice, as well as suspected helmin-

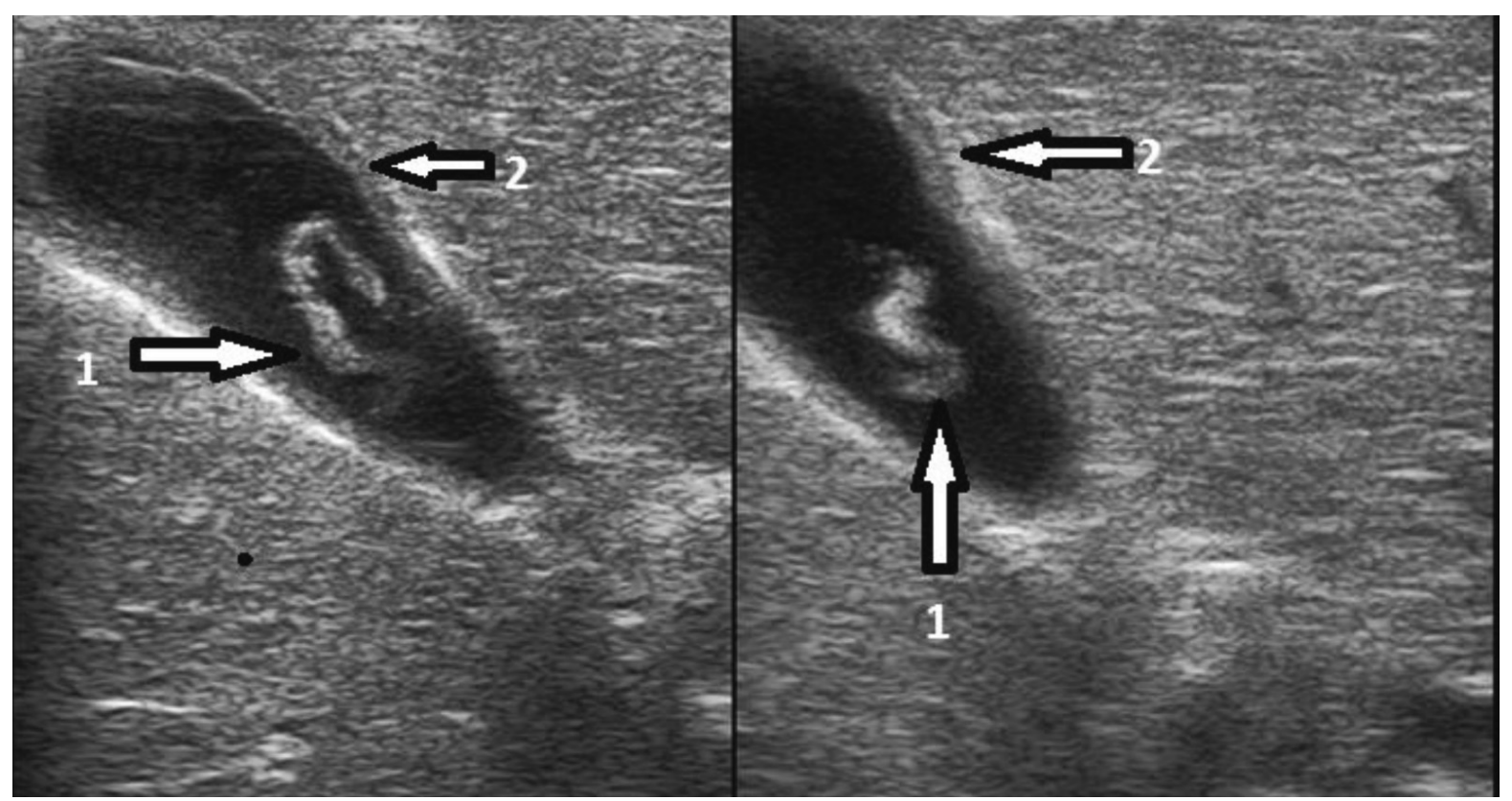

Fig. 5. US of the gallbladder. Linear probe. 1-ascaris; 2 -gallbladder thickened wall. 
thosis, US or other radiological examination should be performed.

Our studies have demonstrated that patients with ascariasis most often have changes in the liver ultrasonic structure $(82 \%)$ in the form of increased «brightness» due to increased echogenicity of the vascular pattern, which may be explained by some changes in the acoustic characteristics of the parenchyma. It is worth noting that similar changes were registered in only $14 \%$ of control group children. Thus, this feature is not universal for ascariasis, but may be taken into account when examining patients with abdominal pain complaints. However, none of the investigated patients with ascariasis had ultrasound changes in the pancreas and spleen compared to the control group.

The reaction of the abdominal cavity lymphatic system to helminth invasion was characterized by a significant increase in the size and number of lymph nodes, mostly localized at the mesentery root and ileocecal region. Of the total detected lymph nodes $(336-100 \%) 318(94.6 \%)$ were in patients with ascariasis. This reaction of the lymphatic system is explained by the fact that the parasites are localized in the small intestine and injure its wall in the process of their activity.

Hydrosonography identified certain morphofunctional changes in the stomach and esophagus that are observed in children with ascariasis and can also cause an abdominal pain. So, fasting fluid in the stomach and antiperistaltic waves were almost twice common at ascariasis: $81 \%$ at ascariasis, versus $43 \%$ in the control group and $69 \%$ at ascariasis, versus $35 \%$ in the control group, respectively. Gastroesophageal reflux in 73 $\%$ of patients indicates the effect of helminths on the state of neuro-humoral regulation of gastrointestinal motility. Parasites in the lumen of the stomach and intestine were not detected in any cases. However, it is worth noting that sonography is one of the best methods in the visualization of roundworm in the gastrointestinal tract $[6,7,9]$.

There is practically no data in the scientific literature regarding a comprehensive assessment of the abdominal organs at ascariasis. At the same time, the researchers' attention is focused on the surgical complications of ascariasis in the form of perforations of the hollow organs and abscesses in order to determine the cause of the disease and to localize the possible focus $[7,11]$.

In our study, the localization of the parasite in the gall bladder cavity without signs of acute in- flammation and perforation of the wall was registered only in 1 case.

\section{Conclusion}

The studies have proved that at ascariasis in children the signs of involvement in the pathological process of the hepatobiliary system, in particular, the liver, are determined. The development of parasitic invasion is also accompanied by an increase of mesenteric lymph nodes and functional changes from the stomach and esophagus in the form of gastroesophageal reflux.

Direct visualization of parasites in the hollow organs' lumen with ultrasound methods is possible, but in a small number of cases as casuistic finds. Ultrasound is the method of choice in the investigation of patients with ascaridosis and allows to adjust antiparasitic therapy depending on the condition of the abdominal organs.

The authors declare no conflict of interest.

\section{Literature}

1. Некоторые факторы иммунитета у больных аскаридозом и энтеробиозом на фоне лечения албендазолом: автореф. дис. на соискание уч. степени канд. мед. наук: спец. 14.00 .10 / Н. Н. Благова // Ярославская мед. академия. - СанктПетербург, 1997. - 20 с.

2. Бронштейн А. М. Современное состояние проблемы нематодозов, цестодозов и трематодозов / А. М. Бронштейн, Н. А. Малышев, В. И. Лучшев // Вестник инфектологии и паразитологии. http:www. Infectology. spb.ru. http://www.infectology.ru/publik/stat19.aspx.

3. Грідіна Т. А. Діагностика рефлюксезофагіту за допомогою гідросонографії / Т. А. Грідіна, Б. А. Тарасюк // Лучевая диагностика, лучевая терапия. - 2016. - № 4. - С. 33-40.

4. Кадочникова Г. В. Аскаридоз у детей, совершенствование диагностики и лечения: автореф. дис. на соискание уч. степени канд. мед. наук: спец. 14.00 .09 / Г. А. Кадочникова // Пермская мед. академия. - Пермь, 2004. - 28 с.

5. Bethony J. Soil-transmitted helminth infections: ascariasis, trichuriasis, and hookworm / J. Bethony, S. Brooker, M. Albonico // Lancet. 2006. - Vol. 367 (9521). - P. 1521-1532. http://doi. org/10.1016/S0140-6736(06)68653-4. 
6. Chokkappan K. The inner tube sign in Ascariasis / K. Chokkappan, M. Subramanian // Abdominal Radiology. - 2019. - Vol. 44. - P. 1193-1194. https:// doi.org/10.1007/s00261-018-1853-0.

7. Dold C. Ascaris and ascariasis / C. Dold, C. V. Holland // Microbes and Infection. - 2011. - N 13. - P. 632-637. https://doi.org/10.1016/j. micinf.2010.09.012.

8. Katz N. A simple device for quantitative stool thick-smear technique in schistosomiasis mansoni / N. Katz, A. Chaves, J. Pellegrino // Rev. Inst. Med. Trop. Sao Paulo. - 1972. - N 14. - P. 397-400.

9. Khuroo M. S. Hepatobiliary and pancreatic ascariasis / M. S. Khuroo, A. A. Rather, N. S. Khuroo //World Journal of Gastroenterology. - 2016. - N 22(33). - P. 7507-7517. https://doi.org/10.3748/wjg. v22.i33.7507.

10. Koumanidou C. Sonographic features of intestinal and biliary ascariasis in childhood: case report and review of the literature / C. Koumanidou, E. Manoli , A. Anagnostara // Ann. Trop. Paediatr. - 2004 - Vol. 24. - P. 329-335. https://doi. org/10.1179/027249304225019154.

11. Lamberton P. H. Human Ascariasis: Diagnostics Update / P. H. Lamberton, P. M. Jourdan // Curr Trop Med Rep. - 2015. - N 2. - P. 189-200. https:// doi.org/10.1007/s40475-015-0064-9.

12. World Health Organization (2006) Preventative chemotherapy in human helminthiasis: coordinated use of anthelminthic drugs in control interventions: a manual for health professionals and programme managers. Available: [http://whqlibdoc. who.int/publications/2006/9241547103_eng.pdf], accessed: 08 July 2015.

\section{FEATURES OF THE ECHOSTRUCTURE OF THE ABDOMINAL ORGANS IN CHILDREN WITH ASCARIASIS}

\section{B.A. Tarasyuk, I.S. Lukyanova, I.N. Dykan,} O.V. Golovchenko, T.A. Gridina, N.T. Reminnaya

Ascaridosis is a common parasitic infection among children that can cause various complications. The aim of the study was to determine the condition of the abdominal organs according to ultrasound diagnostics in children with a confirmed diagnosis of ascariasis. 45 children with ascariasis and 35 children of the control group were examined. It was determined that in most cases in the group with ascariasis the following changes are recorded: an increase in the "brightness" of the liver texture, an increase in the size of mesenteric lymph nodes, and the presence of a gastroesophageal reflux.

Key words: ascariasis, children, ultrasound diagnostics, liver, mesenteric lymph nodes, hydrosonography, stomach, esophagus.

\section{ОСОБЛИВОСТІ ЕХОСТРУКТУРИ ОРГАНІВ ЧЕРЕВНОЇ ПОРЖНИНИ У ДІТЕЙ 3 АСКАРИДОЗОМ}

\section{Б.А.Тарасюк, І.С.Лук'янова, І.М.Дикан, О.В. Головченко, Т.А.Грідіна, Н.Т.Ремінна}

Аскаридоз $є$ розповсюдженою паразитарною інфекцією серед дітей, яка може викликати різноманітні ускладнення. Метою дослідження було визначення стану органів черевної порожнини за даними ультразвукової діагностики у дітей з підтвердженим діагнозом аскаридозу. Обстежено 45 дітей $з$ аскаридозом та 35 дітей групи контролю. Визначено, що у більшості випадків у групі з аскаридозом реєструються наступні зміни: підвищення «яскравості» текстури печінки, збільшення розмірів мезентеріальних лімфатичних вузлів та наявність гастроезофагального рефлюксу.

Ключові слова: аскаридоз, діти, ультразвукова діагностика, печінка, мезентеріальні лімфатичні вузли, гідросонографія, шлунок, стравохід

\section{ОСОБЕННОСТИ ЭХОСТРУКТУРЫ ОРГАНОВ БРЮШНОЙ ПОЛОСТИ У ДЕТЕЙ С АСКАРИДОЗОМ}

\section{Б.А.Тарасюк, И.С.Лукьянова, И.Н.Дыкан, О.В. Головченко, Т.А.Гридина, Н.Т.Реминная}

Аскаридоз является распространенной паразитарной инфекцией среди детей, которая может вызвать различные осложнения. Целью исследования было определение состояния органов брюшной полости по данным ультразвуковой диагностики у детей с подтвержденным диагнозом аскаридоза. Обследовано 45 детей с аскаридозом и 35 детей группы контроля. Определено, что в большинстве случаев в группе с аскаридозом регистрируются следующие изменения: повышение «яркости» текстуры печени, увеличение размеров мезентериальних лимфатичних узлов и наличие гастроэзофагеального рефлюкса.

Ключеье слова: аскаридоз, дети, ультразвуковая диагностика, печень, мезентериальные лимфатические узлы, гидросонография, желудок, пищевод. 